FACTA UNIVERSITATIS

Series: Economics and Organization Vol. 18, № 4, Special Issue, 2021, pp. 369 - 381

https://doi.org/10.22190/FUEO210817026B

Review Paper

\title{
MOVING FROM NON-FINANCIAL TO SUSTAINABILITY REPORTING: ANALYZING THE EU COMMISSION'S PROPOSAL FOR A CORPORATE SUSTAINABILITY REPORTING DIRECTIVE (CSRD)
}

\author{
UDC 657.3
}

\begin{abstract}
Josef Baumüller ${ }^{1}$, Stefan O. Grbenic ${ }^{2}$
${ }^{1}$ Vienna University of Economics and Business, Vienna, Austria

${ }^{2}$ Graz University of Technology, Graz, Austria

ORCID iD: Josef Baumüller (ib) https://orcid.org/0000-0001-8274-9338

Stefan O. Grbenic (ib https://orcid.org/0000-0003-1245-5929

Abstract. Non-financial reporting as established through the NFRD (2014/95/EU) has become a core element of the EU Commission's ambitions to transform the European economy towards more sustainability. To address the increased criticism which meets the current reporting requirements, the EU Commission initiated the development of a new set of European Sustainability Reporting Standards, followed by issuing the proposal for a new directive to supersede the NFRD. This paper analyzed these proposals in the light of previous findings from academia and corporate practice, contributing to an ex-ante impact assessment. As a result, it shows that improving completeness, comparability and reliability are the two main goals of the EU Commission. However, many of the new proposed requirements are excessive and raise fundamental questions concerning acceptable levels of administrative burden for companies as well as necessary conceptual fundaments for a reporting framework.
\end{abstract}

Key words: non-financial reporting, sustainability reporting, sustainable finance, NFRD (2014/95/EU); CSR Directive (2021/0104 (COD))

JEL Classification: M41, Q56

Received August 17, 2021 / Revised December 01 / Accepted December 04, 2021

Corresponding author: Josef Baumüller

Vienna University of Economics and Business, Building AD, 1st floor, Welthandelsplatz 1, 1020 Vienna,

Austria |E-mail: josef.baumueller@wu.ac.at

๑ 2021 by University of Niš, Serbia | Creative Commons Licence: CC BY-NC-ND 


\section{INTRODUCTION}

On April 21, 2021, the European Commission published its draft for a new EU directive on sustainability reporting: The Corporate Sustainability Reporting Directive (hereinafter CSRD). The aim of this proposed directive is to supersede the reporting requirements introduced into European accounting law by the Non-Financial Reporting Directive (2014/95/EU; hereinafter NFRD) in 2014. This first directive aimed at improving the transparency in sustainability-related aspects of business activities - and soon became a core element of the far-reaching initiatives of Sustainable Finance (European Commission, 2018) and of the Green New Deal (European Commission, 2019). However, the provisions set forth by the NFRD soon proved to be inadequate in scope and content to keep up with the regulatory development (European Commission, 2021d).

For that reason, the announcements of the Green New Deal have already put forth the aim to improve the provisions of the NFRD (European Commission, 2019). Previous studies and consultations by the EU Commission have pointed out various important fields that required improvements for the European non-financial reporting regime. After a further consultation was carried out in the first half of the year 2020 (European Commission, 2020), the European Commission started with its work on the new directive. Also, the EFRAG's European Lab was mandated to start with the preliminary work on European Non-Financial Reporting Standards. The idea of a new standardization of non-financial reporting was introduced by several stakeholders in the past and it aims at providing more extensive guidelines to the companies in order to improve comparability of the information being reported. At the same time, however, it strengthens the aims of the European Commission to establish a specific European reporting regime that is tailored to the specifics of the ongoing reform program on sustainability within the EU - even at the cost of limited alignment with established international reporting frameworks (Sopp \& Baumüller, 2021).

In early March 2021, the EU Commission published the final reports of the European Lab. Only slightly more than one month later, the proposal for a new directive followed: the CSRD. The consultation period for this proposal was open until mid of July. The first resonance by stakeholder considered the new rules that were put forward as "major step forward in sustainability reporting" (Deloitte, 2021) or even "nothing short of a revolution" (Value Reporting Foundation, 2021). Nevertheless, these reactions indicate that European companies will face considerable changes in their reporting environment with regard to the efforts that they face.

The aim of this paper is to highlight the cornerstones of the proposed CSRD. They are discussed in the light of the previous findings which led to the criticism on and the need to revise the currently applicable NFRD. By addressing these aspects, this paper gives an answer to the question on the implications of the CSRD for the non-financial reporting regime in the EU. Moreover, the consequences that European companies and companies from other countries will face, as well as needs for further clarifications in the proposals are concluded.

With regard to the limitations of this study, it shall be noticed that several aspects covered by the CSRD - such as issues related to the audit (verification) of the disclosed non-financial information - are only briefly addressed and not expanded upon for further discussion, see e. g. Velte, 2021). This paper's focus lies on the overall architecture and on reporting-related core issues of the CSRD. Furthermore, the question whether or not the proposals seem adequate to truly put sustainability deeper in the hearts of European 
companies or run the risk of merely inducing new and different forms of greenwashing is not in the focus of this paper. Also, an empirical study on the practical implications for European companies as contrasted by their current reporting practices is not conducted (see e. g. Zülch et al., 2021).

\section{ELEMENTS OF THE NEW SUSTAINABILITY REPORTING REGIME}

\subsection{Overview}

The CSRD replaces the provisions of the NFRD and completely reshapes the European reporting framework on sustainability reporting. On the one hand, it extends the scope of companies forced to publish such reports substantially and, on the other hand, it proposes a considerable number of new topics that must be reported. These new requirements are outlined in the subsequent chapters.

What is striking at first is the change in the name of the requirements put forth by the directive from "non-financial" to "sustainability" reporting. This follows the criticism that was increasingly prevalent on the vagueness of the term "non-financial", being criticized for just representing a negation without carrying a defined (positive) content. For that reason, the European Lab already proposed this change in terminology in its final reports on European Sustainability Reporting Standards (European Lab, 2021). Besides, the well-established concept of sustainability reporting is characterized by certain features such as a dominant inside-out view on reporting contents that the EU Commission also wants to stress with its proposed new reporting requirements (Baumüller, 2020).

Furthermore, the proposals of the CSRD aim at aligning the European provisions for corporate sustainability reporting with the further requirements put forth by other sustainability-regulated regulations. Most importantly, two other legal acts published in 2019 and 2020, respectively, force companies to extend their reporting: First, the Sustainable Finance Disclosure Regulation (hereinafter SFDR) (2019/2088) requires specific sustainability-related disclosures for companies working in the financial services sector. Especially, the extent to which investments in financial products are sustainable must be disclosed in a quantified manner. Second, the Taxonomy Regulation (2020/852) contains fundamental definitions on environmental sustainability within the EU and amends the reporting requirements of the SFDR. Furthermore, all companies that fall under the European reporting regime set forth by the NFRD (or in the future: by the CSRD) must disclose how and to what extent their activities are environmentally sustainable. For financial institutions, this also includes information on their "green asset ratio", requiring an increased transparency on the sustainability-related impacts of their lending (EBA, 2021).

The EU Commission's Sustainable Corporate Governance Initiative is expected to contain further references to the European sustainability reporting regime in the future. Relevant aspects include, among others, an extended responsibility for sustainability along the value chains of companies as well as linking the remuneration systems of board members closer to sustainability metrics (e. g. from the published sustainability reports) (European Commission, 2021a).

Figure 1 summarizes the interconnections between the CSRD and the most important complementing regulations. 


\section{EU Taxonomy}

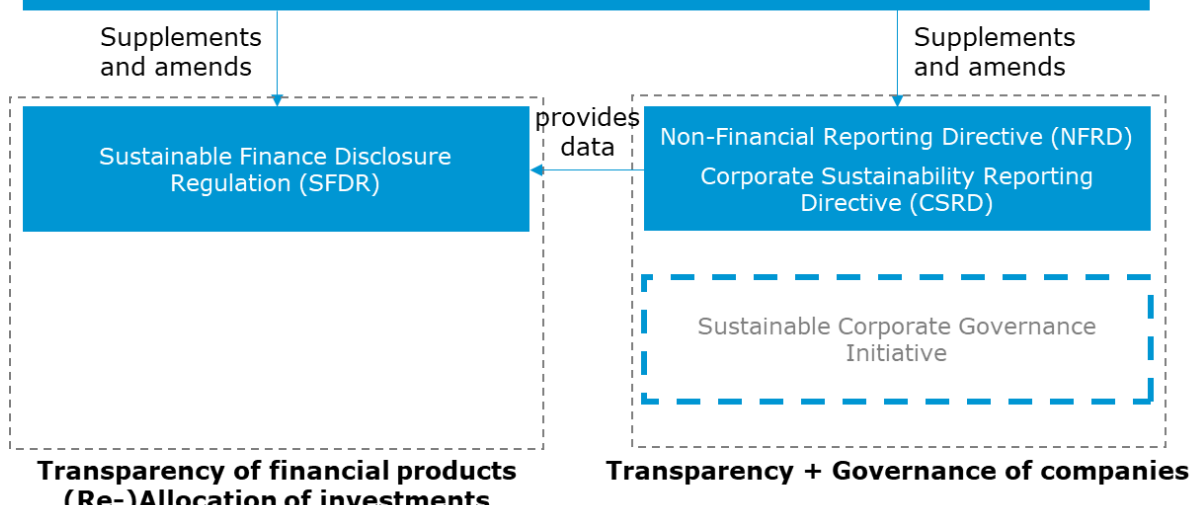

Fig. 1 Regulations addressing the transparency of European companies

The proposals of the CSRD shall apply to financial years starting on or after January 1, 2023. However, they first must be agreed upon on the European level and then, second, they must be transposed into the national laws of the member countries. Although, the number of member state options in the CSRD is limited as compared to the NFRD, heterogeneity is expected since the transposition of the NFRD has already highlighted differences in the efforts to implement sustainability-related regulations of corporate practices (CSR Europe \& GRI, 2017).

Table 1 summarizes the timeline planned to finish the work on the CSRD and for its initial implementation.

Table 1 Proposed timeline (Source: DRSC, 2021a)

\begin{tabular}{ll}
\hline April 21, 2021 & $\begin{array}{l}\text { Official decision on the proposal of the CSRD in the College of } \\
\text { EU Commissioners }\end{array}$ \\
\hline April 2021 to June 2022 at the latest & $\begin{array}{l}\text { Negotiations in the European Council of Ministers and the EU } \\
\text { Parliament } \\
\text { Compromise on the content of the CSRD under the French } \\
\text { Council Presidency }\end{array}$ \\
July 2022 onwards 2022 & $\begin{array}{l}\text { Beginning of transposition into national law } \\
\text { Binding adoption of core standards developed by EFRAG } \\
\text { through delegated act }\end{array}$ \\
by end of October 2022 & $\begin{array}{l}\text { Completion of legal transposition by EU member countries } \\
\text { Beginning of the first financial year in which the new } \\
\text { regulations of the CSRD must be applied }\end{array}$ \\
by December 1, 2022 & $\begin{array}{l}\text { Binding adoption of enhanced standards and SME standards } \\
\text { through delegated acts }\end{array}$ \\
by end of October 2023 & $\begin{array}{l}\text { Publication of the first management reports prepared in } \\
\text { accordance with the new regulations of the CSRD }\end{array}$ \\
January 1, 2024 onwards &
\end{tabular}




\subsection{Scope of application}

One of the most drastic changes proposed by the CSRD refers to the scope of companies that fall under the reporting regime. Whilst the NFRD contains three criteria that have to be met cumulatively ("[i] Large undertakings [ii] which are public-interest entities [iii] exceeding on their balance sheet dates the criterion of the average number of 500 employees during the financial year"), the CSRD extends the scope considerably. Based on the proposals, the following types of European companies will have to draw up sustainability reports: (i) All companies that are publicly traded and operate under the legal form of a limited liability company. Only micro-sized entities are exempted. For small and medium-sized entities, additional time is granted for their preparations (as the proposed reporting require the preparation of the first reports from January 1, 2026, onwards). (ii) All large companies operating under the legal form of a limited liability company, even if they are not publicly traded. (iii) All large insurance companies and banks, irrespective of the legal form they employ (e. g. cooperatives).

For consolidated sustainability reporting, all parents of large groups fall under the scope of the CSRD. Therefore, in contrast to the NFRD, the existence of an obligation to draw up consolidated financial reports is irrelevant (e. g. for reasons of applicable exemptions).

For the first time, also third-country issuers within the EU must prepare sustainability reports based on European law. This aims at establishing a "level play field" for European companies (European Commission, 2021b, p. 11). The requirements of the Transparency Directive (2006/43/EC) are amended accordingly by the CSRD - whilst the exemptions stated in Article 8 of this directive also remain unchanged.

As it is currently the case under the NFRD, subsidiaries are exempted from their obligation to publish sustainability reports if they are included in consolidated reports of their parents. In case the parent is located in a third country, however, the parent's sustainability report must meet the requirements of the sustainability reports published by European companies.

Based on the first assessments of the EU Commission, the increased scope put forward should increase the number of companies that have to publish sustainability reports from approx. 11,600 to 49,000 (European Commission, 2021b, p. 10). For some member states like Germany, however, the actual effect is expected to be much bigger (DRSC, 2021a). This increase is mainly driven by the regulations of the SFDR and the Taxonomy Regulation which require a higher degree of data availability for the financial sector (e. g. European Commission, 2010).

\subsection{Reporting contents}

The concept of materiality is the cornerstone of the current non-financial reporting requirements set forth by the NFRD - as well as for most other frameworks and standards addressing sustainability-related information. One of the most notable changes made to the European sustainability reporting regime is the - explicit - introduction of the principle of "double materiality" (Baumüller \& Sopp, 2021). In order to assess which sustainability matters have to be reported on, companies have to consider both matters that impact their financial performance and position in the short, medium and long term - as well as the impacts of their business activities on these matters. I.e., for the first time it is clearly stated that a reporting obligation also exists for sustainability matters that are only material from one of the two stated perspectives, e. g. associated with relevant impacts on the environment but 
without financial relevance to the reporting company (Adams et al., 2021). This is in line with previous demands addressed to European companies by the EU Commission as well as other stakeholders (especially NGOs). Additionally, it reflects the essence of a sustainability reporting system as compared to the previous requirements for non-financial reporting (Baumüller \& Omazic, 2021). However, findings on the application of the ambiguous principle of materiality as set forth by the NFRD shows that European companies obviously struggle to understand or translate the principle of double materiality into practice. In parts, this might be attributable to specific challenges with regard to its operationalization (CEPS, 2020). In that respect, also the proposals put forth by the CSRD do not bring clarity to the question of how to apply the principle of double materiality.

Furthermore, the CSRD also proposes extended reporting requirements for those topics that are identified as material. Besides the information that is already required by the NFRD, new requirements address: (i) extended reporting contents (aims and strategies), (ii) applicable time frames (retrospective and forward-looking information is required), and (iii) newly structured and extended reporting matters (governance matters; more focus on value chain).

These fundamentally changed reporting requirements obviously reflect the criticism on the NFRD's current requirements that reporting practices were inadequate, are too often lacking depth, and are too often lacking a clear connection to the companies' strategies and governance processes (Alliance for Corporate Transparency, 2020). It seems that for the same reason, the process of materiality analyses must be disclosed by companies and the comply-or-explain principle is dropped. Inconsequently, the CSRD still includes a safeguard clause which allows companies to omit information under certain (very restrictive) circumstances. But, since the application of the identical option in the current NFRD is associated with many questions, the practical relevance of this provision is limited (and would have merited at least further clarification; Baumüller, 2020).

Adding to that, a new reporting requirement addresses information on intangibles that are not reported in the financial statements. The CSRD refers to intellectual, human, social and relationship capital, but also stresses the importance of information on research and development. Nevertheless, the essence of this requirement remains vague, especially as the definitions at the beginning of the EU Commission's proposals link this reporting obligation to the process of value creation by companies (European Commission, 2021b, Article 1 paragraph 2) - a concept which is grounded on the ideas of integrated reporting and thus new to European accounting law. Further references that seem applicable address the ongoing efforts by the EFRAG in terms of accounting for intellectual property rights (EFRAG, 2021) as well as the initiatives towards the concept of natural capital accounting (Capitals Coalition, 2021). Again, further clarification is to be expected in any case.

All companies under the regime of the CSRD additionally have to apply Article 8 of the Taxonomy Regulation. This regulation forces them to report the extent to which their revenues, capex and opex are environmentally sustainable as set forth by that regulation. For companies that already fall under the regime of the NFRD, the reporting requirements of the Taxonomy Regulations already must be applied for reports published in the year 2022 . Currently, these companies face considerable challenges in implementing the relevant processes and collecting data to meet their upcoming obligations (EnBW, 2021). For companies which just fall under the extended scope of the CSRD for sustainability reporting, Article 8 of the Taxonomy Regulation will have to be applied for reports published in the year 2024 and later. 


\subsection{Standardization}

A new element introduced by the CSRD to European sustainability reporting is the standardization of reporting requirements. Besides the basic requirements put forth by the CSRD itself, the EU Commission mandates the EFRAG to become a full-fledged standard setter and to develop detailed standards applicable for all companies falling under the regime of the directive (McGuinness, 2021).

The EU Commission's proposals widely follow the suggestions put forth by the EFRAG in early 2021 (European Lab, 2021). The new standards shall include sector-agnostic, sectorspecific and company-specific information. The relevant reporting matters comprise environmental, social and governance matters (ESG) - thus changing the structure of the current NFRD. For each of these matters, a minimum of topics to be captured is given. By October 31, 2022, a first set of standards shall be adopted reflecting the information needs of financial market participants subject to the SFDR (2019/2088), implying a focus on environmental matters. By October 31, 2023, a second set of standards shall be published to introduce sector-specific reporting requirements. Furthermore, this second set shall also include specific reporting requirements for SME.

As the EFRAG is a private organization, the standards that will be developed have to be endorsed by the EU Commission. This is intended to be done via delegated acts, following a specific endorsement mechanism based on systematic criteria defined by the CSRD. Delegated acts become immediately applicable in all EU member countries and, thus, require no further transposition.

The directive requires the EU Commission to consider relevant development in the works of global standard-setting initiatives, e. g. by the IFRS Foundation or with regard to Natural Capital Accounting. However, this requirement still seems vague and will require further clarification once the CSRD enters into force and the first delegated acts are to be adopted. So far, this aspect of the proposed directive seems to attract considerable attention since many companies and stakeholders doubt that a European way in sustainability reporting is effective given the international scope of activities that European companies are engaged in (e. g. DRSC, 2021a). But, obviously, the EU Commission's initiative and the project of the IFRS Foundation seem to move in different directions concerning the structure and priorities of the developed standards, which might induce considerable complexity and cost for European companies having to consider both developments in their reports factually (Lanfermann et. al., 2021).

Furthermore, the CSRD refers to mechanisms for assessing the equivalence of standards applied by third-country issuers. This is important with regard to the extended scope of the proposed reporting obligations as well as to exemptions applicable for European subsidiaries of third-country parent companies. Unfortunately, the CSRD again misses any further clarification. This might be due to the fact that the European Sustainability Reporting Standards are also still under construction and, thus, an assessment of potentially equivalent other standards is difficult at the moment. For third-country issuers, however, this is an aspect of utmost importance (and corresponding time pressure).

\subsection{Disclosure}

Concerning the way that sustainability reports are published, the CSRD proposes to abolish the current NFRD's option to either disclose information in the management commentary or as a separate (stand-alone) report. In order to improve the connectivity of 
financial and sustainability-related information, only a publication as part of the management commentary shall be possible. However, it is not specified whether this shall be made in the form of a separate chapter of the management commentary or even fully integrated into its various chapters. Reflecting the current practice in many EU member countries showing a prevalence of separate non-financial reports (e. g. DRSC, 2021b), this would imply the need for a fundamental change in the reporting practice having impact on the amount and the style of reporting of information as well as on the costs associated (CEPS, 2020). Conceptually, it introduces inconsistencies with the traditional focus of financial reporting in the management commentary - given the extended perspectives that have to be taken into consideration (Müller et al., 2021).

Furthermore, the CSRD requires companies to prepare their sustainability information in a single electronic reporting format (following the ESEF regulation). This is of fundamental importance to the plans of the EU Commission to introduce the European Single Access Point (ESAP) being announced in the Capital Markets Union Action Plan. By this ESAP, a universal accessibility of the information generated by companies with regard to their financial and sustainability-related performance would be achieved (European Commission, 2021c). This link is of high importance for financial market participants in order to fulfill their reporting requirements as mandated by the SFDR.

\subsection{Corporate governance}

Ultimately, the CSRD focuses on governance mechanisms within companies that underlie their sustainability reporting regime. Specifically, it addresses both internal and external mechanisms. This focus refers to the criticism on the limited reliability of information published by companies.

Concerning internal governance mechanisms, the duties of the management and supervisory board are addressed. First, the responsibility statement of the management boards is extended to sustainability information. Second, the responsibilities of the audit committee are also extended to the sustainability reporting of companies. With regard to the proposed new reporting requirements themselves, also the need to report on the role of the administrative, management and supervisory bodies for sustainability matters as well as on the link to the company's strategies forces these boards to further engage in the relevant matters.

Concerning external governance mechanisms, the mandatory assurance of published sustainability reports is introduced. The company's auditor shall be responsible to assess the compliance of the published sustainability reports along with the requirements of the CSRD. Specifically, the directive stresses four fields to focus the work on: (i) the compliance of the sustainability reporting with the European Sustainability Reporting Standards developed by the EFRAG, (ii) the adequacy of the process of materiality analysis carried out, (iii) the compliance with the requirement to mark-up sustainability reporting in accordance with the ESEF regulation and (iv) the compliance with the reporting requirements of Article 8 of the Taxonomy Regulation.

Besides the auditors of the financial statements published by the company, also other assurance providers - as specified by the CSRD - can be mandated to perform these assessments. For the first three years, these assessments must be based on the level of "limited assurance"; subsequently, the EU Commission is required to evaluate the provisions of the CSRD and to consider the introduction of more extensive requirements with regard to 
"reasonable assurance" (European Commission, 2021b, p. 12). The latter would reflect the demand formulated by many stakeholders in order to ensure equal levels of reliability for financial and sustainability-related information (e. g. AK Europe, 2020). However, at least for the beginning, serious concerns about the robustness of established data collection processes and systems as well as the methodologies employed and capacities by assurance providers seem to have played a vital role for these proposals set forth by the CSRD (e. g. Accountancy Europe, 2020).

With regard to the provision of external assurance, the CSRD contains several requirements, e. g. for professional training and education of the assurance providers and for securing their professional independence. Furthermore, the application of the European enforcement regime on the published sustainability reports is explicitly stated. Finally, detailed provisions for penalties applicable in the case of violations against the reporting obligations are also included in the directive.

\section{DISCUSSION AND IMPLICATIONS FOR COMPANIES IN AND OUTSIDE THE EUROPEAN UNION}

The CSRD represents one further step towards more explicit and extensive reporting requirements with regard to sustainability matters. By that, it ultimately abandons the idea of voluntary (reporting) practices or the sole reliance on market mechanisms to drive company reporting. This is obviously a reaction to the shortcomings of the current reporting regime under the NFRD - also in the light of the high time pressure given to achieve sustainable change in the global economy because of urgent issues such as climate change and its impact on mankind. However, this development also runs the risk of crowding out the sincere ambitions of many to contribute to this required sustainable change as well as of increasingly introducing a "tick-box mentality" to (European) sustainability reporting (Adams \& Abhayawansa, 2021). Furthermore, the detailed requirements of the future reporting regime aim at inducing change to company behavior, by distinguishing "right" from "wrong" in their actions at least in an implicit way. The question in how far a political body like the European Commission has the legitimacy to act in such a prescriptive way remains open for further discussion.

The reporting requirements of the CSRD require an increased amount of information that has to be reported on the sustainability performance. Beyond this reporting content, also the underlying reporting processes (e. g. for materiality analyses) and governance structures (e. g. with regard to the responsibilities of the boards) are addressed by the proposals. This will require additional efforts and considerable investments even from companies that already fall under the regime of the NFRD. Although the CSRD is still a draft version for the new standard and variations in the detailed reporting requirements are possible, companies seem well advised to take the proposed reporting requirements as the starting point for their preparations as soon as possible.

Even more challenges will be faced by companies that currently do not fall under the regime of the NFRD but will have to start with their preparations for publishing the first sustainability reports in accordance with the CSRD in 2024. The fact that only in mid2022 the final version of the CSRD is expected to be published and the transposition into national law is currently required by the end of the same year implies that the time for these companies for their preparation will be even shorter. Based on the current proposal 
of the CSRD, especially large European corporations that are currently not in the scope of the NFRD will face considerable challenges (Hommelhoff, 2021). However, the first outlook on the future sustainability reporting standards that are developed by EFRAG also show that pressure on all companies as well as associated reporting costs will probably be high (DAI, 2021).

But also third-country issuers within the EU are well advised to pay immediate attention due to the perspective of being obliged to apply the requirements of the CSRD. The mechanisms for assessing the equivalence of international or foreign frameworks will play an important role with regard to the extent to which these companies face additional costs and challenges by the CSRD. The same relevance is given for companies from third countries that are not publicly traded on European regulated markets, but have (large) subsidiaries operating within the EU.

But not only companies that fall under the regime of the CSRD, both inside or outside of the EU, are affected by these changing reporting requirements. A mediate effect is to be expected due to the demand from the European capital markets for sustainability-related information. Furthermore, since companies in its scope must report on the impacts along their value chain, they might require additional information from their business partners. As a consequence, virtually every company that engages in business activities within the EU should consider the possible impact of the proposed new reporting requirements on its own (legal or just factual) reporting obligations, processes and governance structures (KPMG, 2020).

With regard to the further negotiations on the CSRD and its practical acceptance inside and outside of the EU, its relation to the project by the IFRS Foundation to publish its own set of sustainability reporting standards will be of high importance. For companies, the perspective of having to adhere to two different set of standards at the same time seems repelling because of assumably higher reporting compliance costs and the possible risk of increased complexity and confusion associated with parallel reporting practices. Business representatives responded to this threat by increasing their pressure on the EU Commission to follow the global developments aiming at establishing a "baseline" for sustainability reporting - which could imply that the IFRS Foundation's standards serve as the starting point for core reporting requirements around the world to which jurisdictions such as the EU add additional requirements given the specifics of their reporting environments and different political priorities (World Economic Forum, 2021). Both from a conceptual perspective as with regard to the practical implications of the many initiatives on the field of sustainability reporting on a global level, this approach seems promising in order to arrive at a balance between ambitious regulations towards sustainable development and pragmatic needs from practice. However, so far the EU Commission has hardly shown signs to step down from its high ambitions and to integrate its project into the broader scope of international developments on the field of sustainability standard-setting and current convergence initiatives. This underlines the political perspective of the current changes in the reporting landscape; given the momentum surrounding the IFRS Foundation's project and its increased relevance as further illustrated by the mergers of existing international standard setters with its newly established International Sustainability Standards Board (ISSB) (IFRS Foundation, 2021), the EU Commission's proposals face the considerable risk of lacking their relevance on a global scale and thus missing one of their main aims. 


\section{CONCLUSION}

Via the CSRD, the EU Commission aims at improving the completeness, comparability and reliability of sustainability reports within the EU. Furthermore, gaps in the relevant sustainability-related European regulations are closed - especially with regard to the SFDR and the Taxonomy Regulation. For that reason, the scope of companies that must apply the reporting regime as well as the elements of these reports are considerably increased. Thus, it seems justified to call the proposals published on April 21, 2021, a major step forward in the field of corporate transparency.

However, this development comes at a cost that are borne by European companies that must invest into their processes and structures in order to come up with improved reports. The impact of these changes on the corporate decision-making is the ultimate goal of the recent flood of regulations that address sustainability within the EU (e. g. European Lab, 2021).

Still, specific points can be outlined that merit further consideration. Many requirements of the CSRD are still vague or raise important questions with regard to the alignment with existing (international or foreign) frameworks and standards. The high time pressure that is put on companies along with the uncertainties they currently face about the contents of both the final version of the CSRD and the European Sustainability Reporting Standards raise serious concerns. There seem to be good reasons for slowing down and reflecting the cost to benefit relation of the proposed regulation. However, the experiences from the past few years show that the EU Commission is following its sustainability-related aims with considerable determination and might not pay enough attention to the needs of corporate practice.

These developments are not only important within the EU but also for companies located in third countries. Other jurisdictions are increasingly turning towards the EU Commission's initiative and try to come up with similar solutions (KPMG, 2020). But also the CSRD extends its scope of application to these companies for the first time. Consequently, there is a need for all these companies to analyse the impacts of the EU Commission's proposals on them and to deduct the need for appropriate reactions as soon as possible.

The importance of sustainability per se and of invigorated behaviour by companies into the direction of sustainable development seems to have become a global consensus over the recent years. So, on the one hand, whatever the future way might be, there is probably no way back. But, on the other hand, along with all the challenges arising, also new business opportunities will materialize.

\section{REFERENCES}

Accountancy Europe (2020). Setting up for high-quality non-financial information assurance in Europe, Position paper. Retrieved from: https://www.accountancyeurope.eu/wp-content/uploads/200609-AccountancyEurope-setting-up-for-quality-non-NFI-assurance-paper.pdf. Accessed on: June 26, 2021.

Adams, C., \& Abhayawansa, S. (2021). Connecting the COVID-19 pandemic, environmental, social and governance (ESG) investing and calls for 'harmonisation' of sustainability reporting. Critical Perspectives on Accounting (In Press). https://doi.org/10.1016/j.cpa.2021.102309.

Adams, C., Alhamood, A., He, X., Tian, J., Wang, L., \& Wang, Y. (2021). The double-materiality concept. Application and issues. Retrieved from: https://www.globalreporting.org/media/jrbntbyv/griwhitepaperpublications.pdf. Accessed on: November 30, 2021.

AK Europe (2020). Accounting for a Sustainable European Economy? Retrieved from: https://www.researchgate.net/ publication/340970139_Accounting_for_a_Sustainable_European_Economy_AK_Europa_Policy_Brief_32020. Accessed on: June 26, 2021.

Alliance for Corporate Transparency (2020). 2019 Research Report, An analysis of the sustainability reports of 1000 companies pursuant to the EU Non-Financial Reporting Directive. Retrieved from: https://en.frankbold. 
org/our-work/campaign/eu-directive-non-financial-reporting-and-corporate-governance. Accessed on: June 26, 2021.

Baumüller, J. (2020). Nichtfinanzielle Berichterstattung [Non-Financial Reporting]. Vienna: Verlag Österreich.

Baumüller, J., \& Omazic, A. (2021). Entwicklungsperspektiven für den Wesentlichkeitsgrundsatz in der nichtfinanziellen Berichterstattung [Development perspectives for the materiality principle in non-financial reporting]. Zeitschrift für Internationale Rechnungslegung, 16(1), 41-47.

Baumüller, J., \& Sopp, K. (2021). Double materiality and the shift from non-financial to European sustainability reporting: review, outlook and implications. Journal of Applied Accounting Research, ahead of print https://doi.org/10.1108/JAAR-04-2021-0114.

Capitals Coalition (2021). Transparent. Retrieved from: https://capitalscoalition.org/project/transparent/. Accessed on: June 26, 2021.

CEPS (2020). Study on the Non-Financial Reporting Directive, Final report. Retrieved from: https://op.europa.eu/de/ publication-detail/-/publication/1ef8fe0e-98e1-11eb-b85c-01aa75ed71a1/language-en. Accessed on: June 26, 2021.

CSR Europe \& GRI (2017). Member State Implementation of Directive 2014/95/EU. Retrieved from: https://www.accountancyeurope.eu/wp-content/uploads/NFR-Publication-3-May-revision.pdf. Accessed on: June 26, 2021.

DAI (2021). Comments on EFRAG Climate Standard Prototype Working Paper. Retrieved from: https://www.dai.de/fileadmin/user_upload/210930_Deutsches_Aktieninstitut_Letter_Mr_Gauzes_EFRAG_ Climate_Standard_Prototype.pdf. Accessed on November 30, 2021.

Deloitte (2021). The EU takes a major step forward in sustainability. Retrieved from: https://www2.deloitte.com/ $\mathrm{fr} / \mathrm{fr} /$ pages/sustainability-services/articles/eu-takes-major-step-forward-sustainability-reporting.html. Accessed on: June 26, 2021.

DRSC (2021a). DRSC Briefing Paper zur CSRD vom 21. April 2021 [DRSC Briefing Paper for the CSRD from April 21, 2021]. Retrieved from: https://www.drsc.de/app/uploads/2021/04/210421_CSRD_BriefingPaper.pdf. Accessed on: June 26, 2021.

DRSC (2021b). CSR-Studie [CSR study]. Retrieved from: https://www.bmjv.de/SharedDocs/Downloads/DE/PDF/ Berichte/2021_CSR_Studie.pdf?_blob=publicationFile\&v=2. Accessed on: June 26, 2021.

EBA (2021). EBA advises the Commission on KPIs for transparency on institutions, environmentally sustainable activities, including a green asset ratio. Retrieved from: https://www.eba.europa.eu/ebaadvises-commission-kpis-transparency-institutions\%E2\%80\%99-environmentally-sustainable-activities. Accessed on: June 26, 2021.

EFRAG (2021). A literature review on the reporting of intangibles, February 2020. Retrieved from: https://www.efrag.org/Assets/Download?assetUrl=\%2Fsites\%2Fwebpublishing\%2FSiteAssets $\% 2$ FA $\% 252$ Oliterature $\% 2520$ review\%2520on\%2520the\%2520reporting\%2520of\%2520intangibles.pdf. Accessed on: June 26, 2021

EnBW (2021). EU sustainable finance taxonomy case study. Retrieved from: https://www.enbw.com/integratedannual-report-2020/at-a-glance/eu-taxonomy/. Accessed on: June 26, 2021.

European Commission (2018). Action Plan: Financing Sustainable Growth, COM/2018/097 final. Retrieved from: https://eur-lex.europa.eu/legal-content/EN/TXT/PDF/?uri=CELEX:52018DC0097\&from=EN. Accessed on: June 26, 2021.

European Commission (2019). The European Green Deal, COM (2019) 640 final. Retrieved from: https://eurlex.europa.eu/resource.html?uri=cellar:b828d165-1c22-11ea-8c1f-01aa75ed71a1.0002.02/DOC_1\&format=PDF. Accessed on: June 26, 2021.

European Commission (2020). Summary Report of the Public Consultation on the Review of the Non-Financial Reporting Directive, February 20, 2020 - June 11, 2020, Ref. Ares (2020)3997889 - 29/07/2020. Retrieved from: https://www.consob.it/documents/46180/46181/Ares\%282020\%293997889_summary_report.pdf/bf9a64eb-3b244ade-bc5e-c7a1e238ca89. Accessed on: June 26, 2021

European Commission (2021a). Sustainable corporate governance. Retrieved from: https://ec.europa.eu/info/law/ better-regulation/have-your-say/initiatives/12548-Sustainable-corporate-governance_en. Accessed on June 26, 2021.

European Commission (2021b). Proposal for a Directive of the European Parliament and of the Council amending Directive 2013/34/EU, Directive 2004/109/EC, Directive 2006/43/EC and Regulation (EU) No 537/2014, as regards corporate sustainability reporting, COM (2021) 189 final. Retrieved from: https://eur-lex.europa.eu/legal-content/EN/TXT/?uri=CELEX:52021PC0189. Accessed on June 26, 2021.

European Commission (2021c). Frequently asked questions on the CSRD proposal. Retrieved from: https://ec.europa.eu/commission/presscorner/detail/en/qanda_21_1806. Accessed on: June 26, 2021.

European Commission (2021d). Commission Staff Working Document, Fitness Check on the EU framework for public reporting by companies, SWD (2021) 81 final. Retrieved from: https://op.europa.eu/en/publicationdetail/-/publication/5defa792-a2a6-11eb-9585-01aa75ed71a1/language-en. Accessed on: June 26, 2021.

European Lab (2021). Final Report - Proposals for a relevant and dynamic EU sustainability reporting standardsetting, February 2021. Retrieved from: https://www.efrag.org/Assets/Download?assetUrl=\%2Fsites\% 
2Fwebpublishing\%2FSiteAssets\%2FEFRAG\%2520PTF-NFRS_MAIN_REPORT.pdf. Accessed on: June 26, 2021.

Hommelhoff, P. (2021). Primärrechtlich begründete Mängel im CSRD-Vorschlag und deren Beseitigung [Primary law-based deficiencies in the CSRD proposal and their elimination]. Der Betrieb, 74(42), 2437-2447.

IFRS Foundation (2021). IFRS Foundation announces International Sustainability Standards Board, consolidation with CDSB and VRF, and publication of prototype disclosure requirements. Retrieved from: https://www.ifrs.org/news-and-events/news/2021/11/ifrs-foundation-announces-issb-consolidation-withcdsb-vrf-publication-of-prototypes/. Accessed on November 30, 2021.

KPMG (2020). RBI: Adoption of the indirect counter-proposal. Retrieved from: https://home.kpmg/ch/de/blogs/home/ posts/2020/11/adoption-of-the-indirect-counterproposal.html. Accessed on: June 26, 2021

Lanfermann, G., Schwedler, K., \& Schmotz, T. (2021). Nachhaltigkeitsberichtsstandards im Fokus der EUGesetzgebung [Sustainability reporting standards in the focus of the EU Commission]. Die Wirtschaftsprïfung, 74(12), 762-767.

McGuinness (2021). Letter to Jean-Paul Gauzès. Retrieved from: https://www.efrag.org/Assets/Download?assetUrl= /sites/webpublishing/SiteAssets/210512+Commissioner+McGuinness+to+EFRAG+on+sustainability.pdf. Accessed on: June 26, 2021.

Müller, S., Scheid, O., \& Baumüller, J. (2021). Kommissionsvorschlag zur Corporate Sustainability Reporting Directive: von der nichtfinanziellen Berichterstattung zur Nachhaltigkeitsberichterstattung [The EU Commission's proposal on the Corporate Sustainability Reporting Directive: from non-financial reporting to sustainability reporting]. Betriebs-Berater, 73(22), 1323-1327.

Sopp, K., \& Baumüller, J. (2021). Auf dem Weg zu europäischen Standards für die nichtfinanzielle Berichterstattung? Teil 1: Projektendbericht des European Corporate Reporting Lab @ EFRAG [Towards European standards for non-financial reporting? Part 1: Project final report of the European Corporate Reporting Lab @ EFRAG]. Zeitschrift für internationale und kapitalmarktorientierte Rechnungslegung, 21(6), 254-268.

Value Reporting Foundation (2021). Creating value managing impact through integrated sustainability disclosure event. Retrieved from: https://integratedreporting.org/news/creating-value-managing-impactthrough-integrated-sustainability-disclosure-event/. Accessed on June 26, 2021.

Velte, P. (2021). Prüfung von Nachhaltigkeitsberichten nach dem Entwurf einer „CSR-Richtlinie 2.0“: Vergleichende Analyse der Reformmaßnahmen und kritische Würdigung [Audit of sustainability reports according to the draft of a "CSR Directive 2.0": Comparative analysis of the reform measures and critical appraisal]. Die Wirtschaftsprüfung, 74(10), 613-620.

World Economic Forum (2021). 60 organizations release open letter for EU to act on ESG. Retrieved from: https://www.weforum.org/agenda/2021/10/57-organizations-release-open-letter-for-eu-to-act-on-esg/. Accessed on November 30, 2021.

Zülch, H., Ottenstein, P., \& Schneider, A. (2021). The New Corporate Sustainability Reporting Directive (CSRD) Proposal - Are German Firms Already Compliant?. Zeitschrift für internationale und kapitalmarktorientierte Rechnungslegung, 21(7-8), 345-348.

\section{PRELAZAK SA NEFINANSIJSKOG NA IZVEŠTAVANJE O ODRŽIVOSTI: ANALIZA PREDLOGA EVROPSKE KOMISIJE ZA DIREKTIVU O IZVEŠTAVANJU O KORPORATIVNOJ ODRŽIVOSTI (CSRD)}

Kako je ustanovljeno kroz NFRD (2014/95/EU), nefinansijsko izveštavanje postalo je ključni element ambicija Evropske komisije da transformiše evropsku ekonomiju ka većoj održivosti. Da bi odgovorila na povećane kritike koje ispunjavaju trenutne zahteve za izveštavanje, Komisija EU je pokrenula razvoj novog seta evropskih standarda za izveštavanje o održivosti, nakon čega je izdala predlog nove direktive koja bi zamenila NFRD. Ovaj rad analizira ove predloge u svetlu prethodnih zaključaka iz akademske zajednice i korporativne prakse, doprinoseći ex-ante proceni uticaja. Kao rezultat toga, pokazuje da su poboljšanje kompletnosti, uporedivosti i pouzdanosti dva glavna cilja Komisije EU. Međutim, mnogi od novih predloženih zahteva su preterani i postavljaju fundamentalna pitanja u vezi sa prihvatljivim nivoima administrativnog opterećenja za kompanije, kao i neophodnim konceptualnim osnovama za okvir izveštavanja.

Ključne reči: nefinansijsko izveštavanje, izveštavanje o održivosti, održive finansije, NFRD (2014/95/EU); Direktiva o društveno odgovornom poslovanju (2021/0104 (COD)) 